\title{
Migration and Employment of Immigrants in the Finnish Local Labor Markets
}

\author{
ELLI HEIKKILÄ, Ph.D., Docent, Research Director \\ TARU JÄRVINEN, M.Sc., Researcher \\ Institute of Migration, Turku, Finland
}

\section{Abstract}

This article concentrates on the special features of country-internal migration of immigrants. The internal migration of immigrants within the country and the growth of urban centers are analyzed on the national level by municipalities and, in more detail, in nine differently structured local labor-market areas. The position of immigrants in the local labor-market areas depends on their educational level. Urban centers with developed, multistructured labor markets have strengthened their edge over others in attracting in-migrants from more peripheral areas in the subgroup of immigrants, as well as in general. Internal and international migrations are related to each other. The larger urban centers and refugee-receiving municipalities play an important role in linking international and internal migration.

Keywords: immigrants, internal migration, labor market status, education

\section{Introduction}

The population of Finland is considered more ethnically homogenous than the populations of most other European countries. Today, the total number of immigrants in Finland is 98,640 , which accounts for only $1.7 \%$ of the total population (Monitori 2002; see Heikkilä and Peltonen 2002).

During the 1980s, the foreign population was still veritably low in Finland; however it doubled during that decade. In the beginning of the $1990 \mathrm{~s}$, immigration began to increase rapidly, which coincided with a deep economic recession (see Forsander 2001). The recession caused mass unemployment among the majority population and 
especially the newcomers. Afterwards employment has only slowly increased, and most immigrant groups are still two or three times more likely to be out of work than the majority population.

This article discusses, first of all, the internal migration of immigrants in Finland by municipalities in 2001 . Usually research on immigration concerns the phenomenon of immigration. Our aim is to go one step further and to look at how immigrants have remigrated within their destination country of Finland. The data does not include those immigrants who have received Finnish citizenship.

Secondly, immigrants and their employment in various types of labor-market areas have been analyzed. Annual gross-stream labor statistics provide useful tools for this analysis. The data allows for multidimensional analysis of labor-market mobility, i.e. in geographical terms as well as between sectors, and according to the qualifications of the labor force. The gross-stream data in this article deals with all 16-74-year-old immigrants who immigrated to Finland in 1996 and follows them up in regard to their labor-market status one year later, i.e. in 1997. Hence, it is possible to determine what has occurred in the labor market by the end of 1997 to an immigrant who was unemployed the year before; whether she/he has been employed following migration, if she/he is still unemployed or perhaps outside the labor force. The education statistics of immigrants are imperfect because of the lack of exact information. Educational background information is available for only one-third of the immigrants and for the others is unknown. All the data has been purchased from Statistics Finland.

In addition to the priorities on the need for research concerning immigrants presented by the Advisory Board for Ethnic Relations (Etnisten suhteiden neuvottelukunta) (1999), the importance of the study was set forth in the research-policy program of the Institute of Migration for the years 2000-2004 (Heikkilä 1999).

\section{The regional distribution and internal migration of immigrants}

The largest groups of immigrants in Finland come from Russia, Estonia, Sweden, Somalia, the former Yugoslavia, Iraq, Germany, the United Kingdom, the United States and Vietnam. The Russians, Estonians, Americans and British are so-called voluntary immigrants, while most of the immigrants from Bosnia-Herzegovina, Iraq, Somalia and Vietnam came to Finland as refugees. The people from Bosnia-Herzegovina, the Iraqis and Somalis arrived in the 1990s, whereas the Vietnamese are a more established immigrant group from the turn of the 1970s and 1980s (Heikkilä and Peltonen 2002).

The immigrants have not been differentiated into separate groups in the analysis; they are seen as comprising a whole. The data does not take into consideration immigrants 
who have received Finnish citizenship. The majority of immigrants are concentrated on the coastal areas in the southern and western parts of the country, and also on the border of Russia in the northeast (Figure 1). In the Kainuu region there is a preponderance of immigrants in Vuolijoki because it is a refugee-receiving municipality. Crossborder marriages and the short distance between Finland and Russia account for the large amount of immigrants in eastern Finland. Over sixty-two percent (62.6\%) of the immigrants in Northern Karelia come from either Russia or the area of the former Soviet Union. Their proportion consists of over half of the immigrant population in the regions of Southern Karelia and Kymenlaakso (see Statistics Finland 2002).

Figure 1. Regional distribution of immigrants in Finland in 2001.

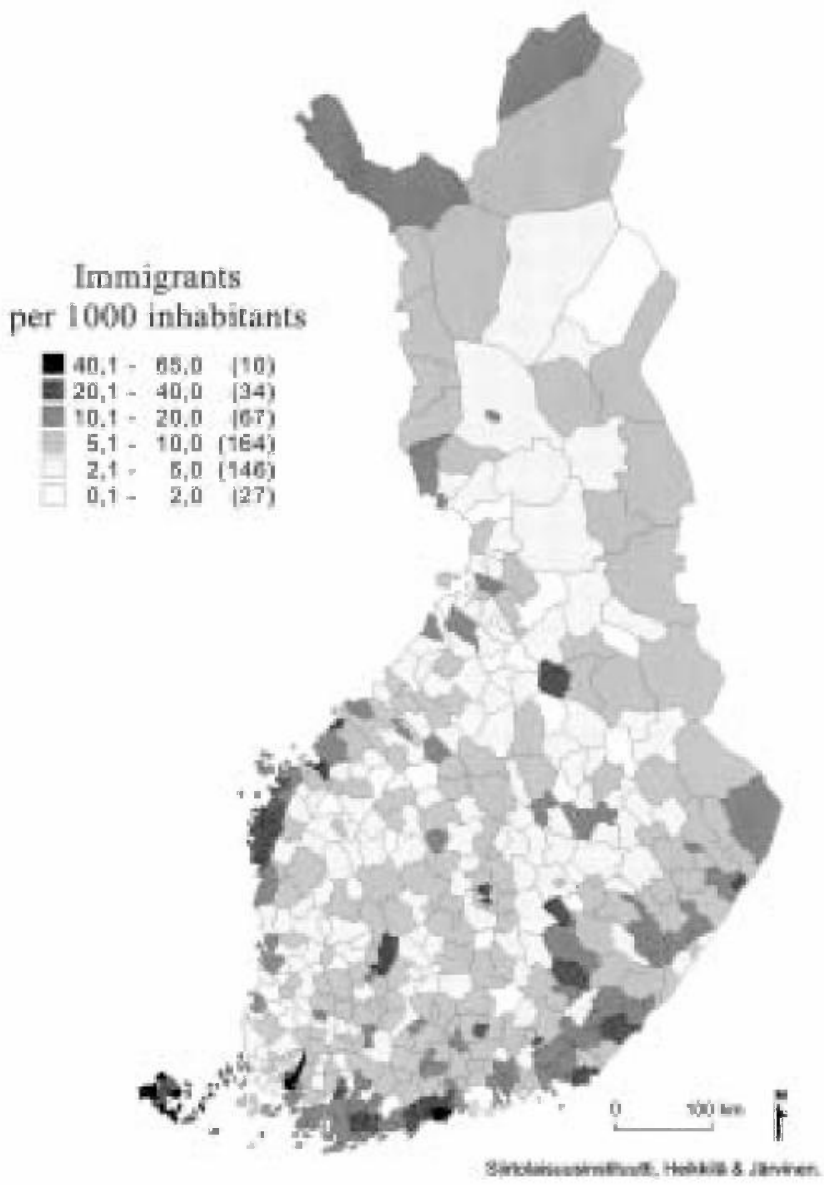

Diverse employment opportunities and services attract immigrants to the southern coastal areas, including the capital area of Helsinki. In the year 2001, the immigrant population was $3.6 \%$ of the total population in the region of Uusimaa, a percentage nearly double the average for the entire country. Half of Finland's immigrants live in Uusimaa. During the 1990s in particular, immigrants heading for Finland settled first and foremost in Helsinki. Later, they moved to the outskirts of the Helsinki conurbation. 
Turku is the second largest area of immigrant concentration in our country after the Helsinki conurbation proportion, which comprises Helsinki, Vantaa, Espoo and Kauniainen. Turku has the third largest amount of immigrants of all Finland's municipalities; only Helsinki and Espoo exceed it in the number of immigrants. In the year 2001 , seventy-three percent of the immigrants to Åland were from Sweden (see Statistics Finland 2002; Kokko 2002).

The internal in-migration of Finland's immigrants has been strongly directed towards five cities: Helsinki (1,545 persons), Espoo ( 812 persons), Vantaa ( 783 persons), Turku (562 persons), and Tampere ( 287 persons) in 2001 (Figure 2). Thus, urban areas have received $53 \%$ of the immigrant influx. The city of Oulu is the only place in northern Finland that has received more than one hundred immigrants, 119 altogether. Fiftyfour percent of the municipalities have received only 1 to 10 immigrants and $28 \%$ of the municipalities have not received any immigrants. Thus, the internal in-migration of immigrants has been rather concentrated in the urban areas, as has internal migration on the whole.

Figure 2. Country-internal in-migration of immigrants in Finland in 2001.

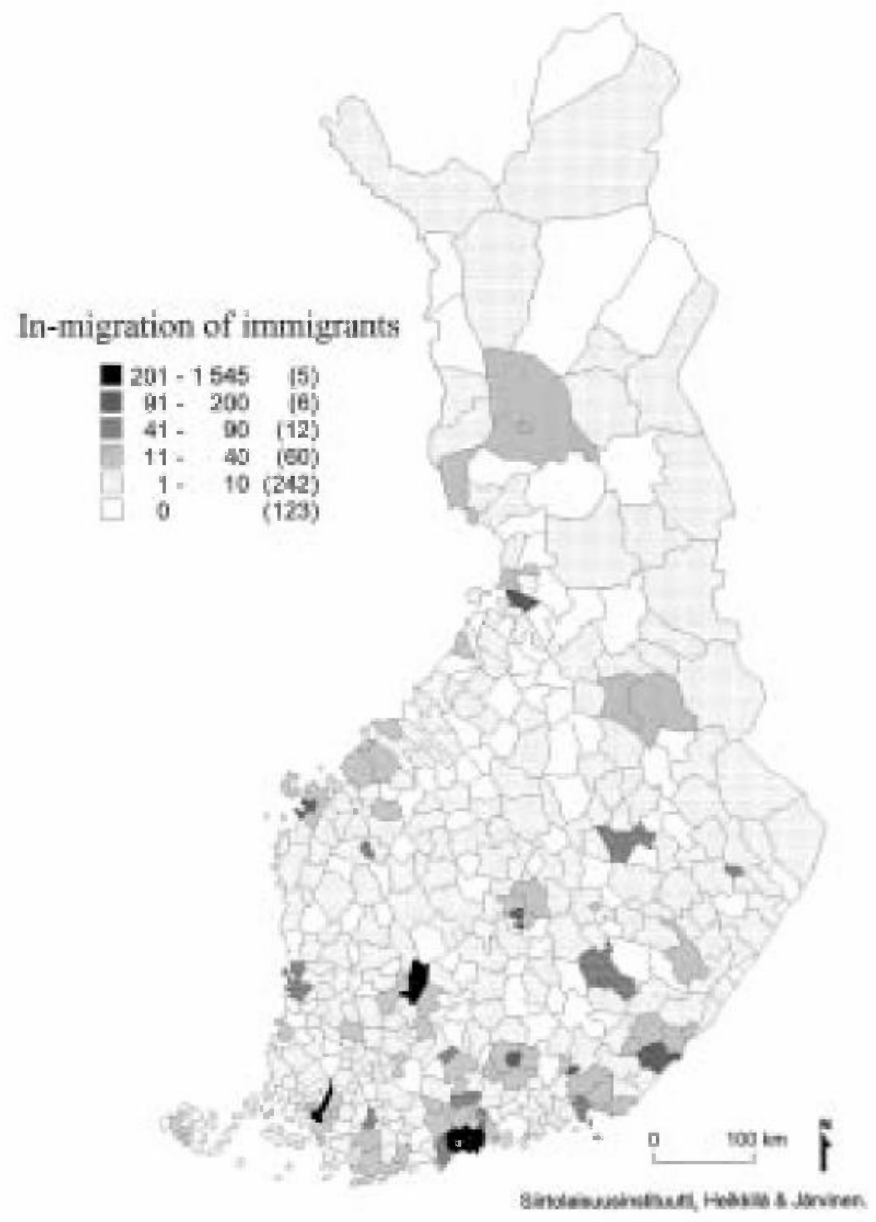


The areas of internal out-migration have been the same as for internal in-migration, i.e. our urbanized areas (Figure 3). The most significant flow of out-migration has been from Helsinki ( 1,230 persons), Vantaa (515 persons), Espoo (471 persons), Turku ( 338 persons), and Tampere ( 276 persons) in 2001. The division of the municipalities into different out-migration groups according to size coincides with the division of municipalities for in-migration.

Figure 3. Country-internal out-migration of immigrants in Finland in 2001.

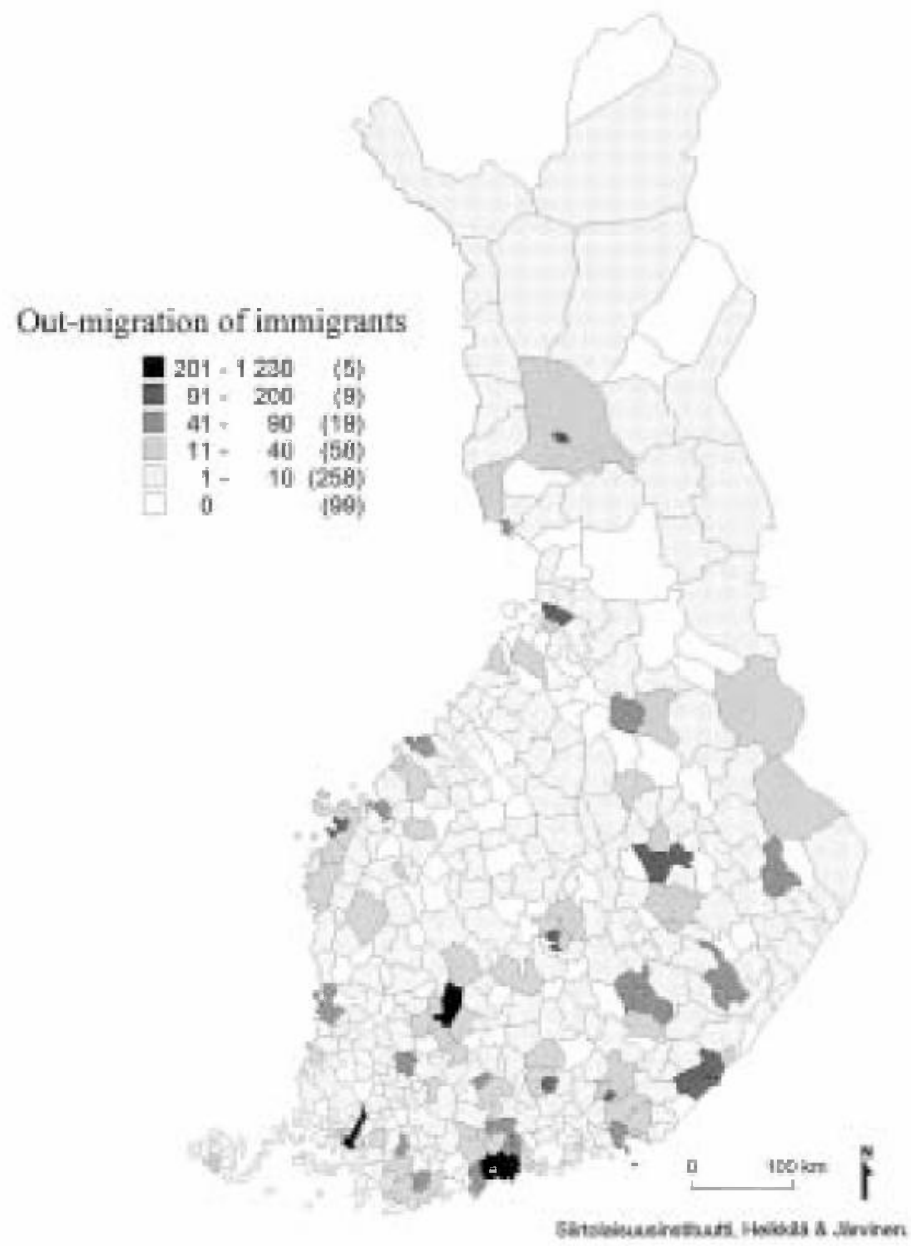

The internal net migration of immigrants has been the highest in Espoo, Helsinki, Vantaa, and Turku (Figure 4; Table 1-2). The number of immigrants has remained rather stable in $95 \%$ of the municipalities: net increases and decreases have been below 20 persons. Ten of the municipalities with the most negative net migration values are refugee-receiving municipalities. The intense net out-migration in these municipalities is due to the fact that immigrants arrive from outside the country and they out-migrate and relocate in other areas within the borders of Finland. Looking at Tables 1 and 2, it is important to realize that although the net amount of in-migration 
and out-migration for an area may seem small, the overall total flows for in-migration and out-migration may be fairly large as in the case of Tampere.

Figure 4. Country-internal net migration of immigrants in Finland in 2001.

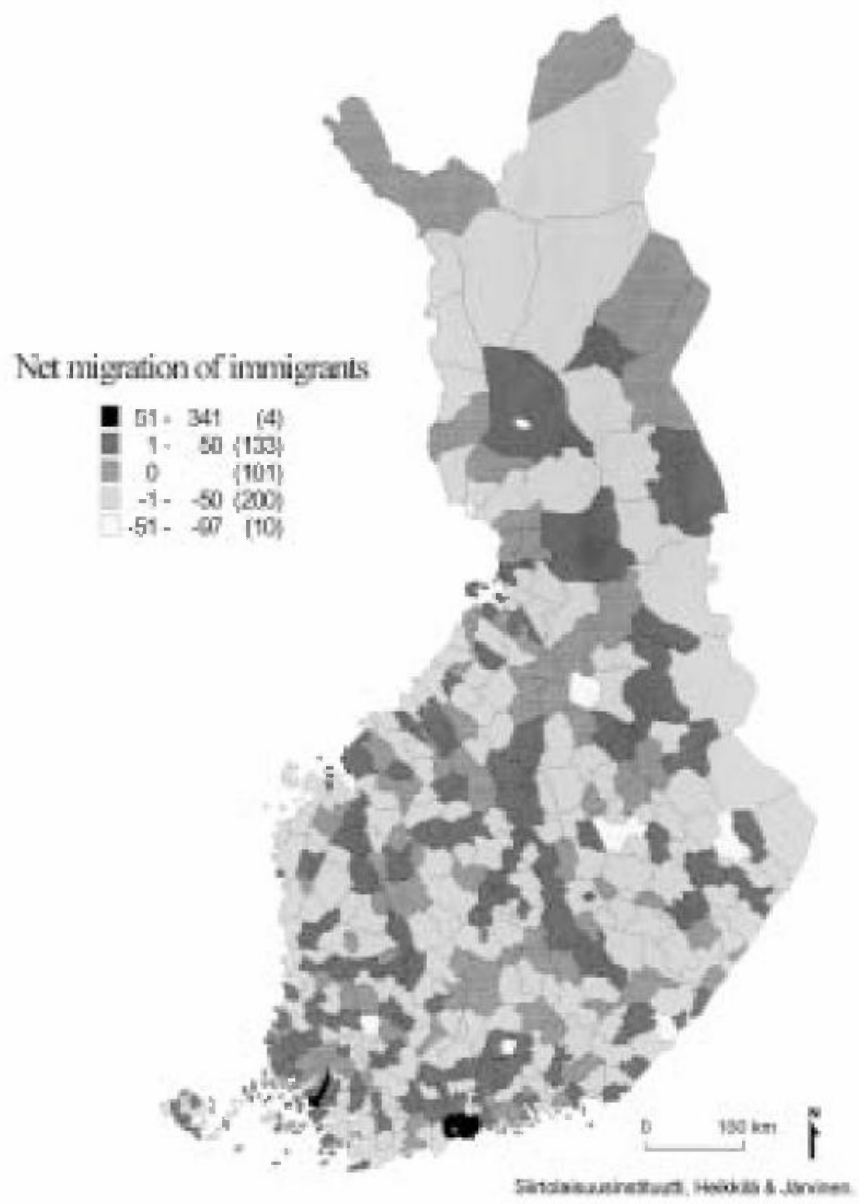

Table 1. Ten municipalities with the highest positive net migration for internal inmigration and out-migration of immigrants.

\begin{tabular}{lccc}
\hline Municipality & In-migration & Out-migration & Net migration \\
\hline Espoo & 812 & 471 & 341 \\
Helsinki & 1,545 & 1,230 & 315 \\
Vantaa & 783 & 515 & 268 \\
Turku & 562 & 338 & 224 \\
Järvenpää & 72 & 49 & 23 \\
Seinäjoki & 50 & 30 & 20 \\
Nurmijärvi & 40 & 21 & 19 \\
Rauma & 38 & 25 & 13 \\
Tampere & 287 & 276 & 11 \\
Sipoo & 26 & 15 & 11 \\
\hline
\end{tabular}


Table 2. Ten municipalities with the most negative net migration for internal inmigration and out-migration of immigrants.

\begin{tabular}{lccc}
\hline Municipality & In-migration & Out-migration & Net migration \\
\hline Joutseno & 11 & 108 & -97 \\
Rovaniemi & 30 & 100 & -70 \\
Oravainen & 2 & 69 & -67 \\
Punkalaidun & 1 & 62 & -61 \\
Kuopio & 83 & 143 & -60 \\
Vaasa & 116 & 175 & -59 \\
Lahti & 108 & 166 & -58 \\
Vuolijoki & 2 & 58 & -56 \\
Kontiolahti & 10 & 61 & -51 \\
Kemi & 15 & 66 & -51 \\
\hline
\end{tabular}

A large portion of internal migration has been between urbanized areas. Immigrants have preferred to settle in cities; $84 \%$ live in urban municipalities (Jaakkola 2000b, 17). Urbanized areas not only offer more employment opportunities and better educational opportunities for children, but immigrants can also form their own communities, which operate more easily in larger areas.

Immigrants are seldom content with the size and the opportunities offered in their first place of settlement. They feel the municipality is too small and does not offer enough opportunities for them. Reasons for moving to a different town or city include loneliness and factors concerning ethnicity and culture. Preserving their culture is an important part of the immigrants' well-being. Maintaining their own culture and ethnicity is usually difficult in their first place of settlement where their own ethnic group may be rather small (Kokko 2002). Factors such as these explain why immigrants move to larger urban centers in southern Finland in search for a more multicultural environment. Pehkonen (2002) has noticed in her on-going dissertation research that it is not always easy even for native Finnish people to move to rural areas as newcomers. Thus, it is understandable that immigrants will remove from smaller settlements to more flexible surroundings.

Likewise, the attitudes of Finnish residents can be seen as a force behind the internal migration of immigrants. Especially in small towns, Finns are often considered narrow-minded and inexperienced with foreigners. Foreigners in this situation feel that they are unable to fit into the mainstream and this in turn weakens their ability to feel at home. Immigrants feel that the Finns living in large cities are more experienced with foreigners and thus more tolerant towards them (Kokko 2002).

The larger urban centers and refugee-receiving municipalities play an important role in linking international and internal migration. The refugee-receiving municipalities are located in different parts of Finland as a function of regional policy. There are a total of 14 municipalities which have receiving centers for asylum-seekers and 137 
municipalities have received refugees. Some of these asylum receiving centers for asylum-seekers are located in more peripheral regions such as Oravainen and Punkalaidun. The purpose of this is to support the population development in outmigration areas. One basis for decentralization is to avoid the concentration of immigrants in a few suburbs.

The municipality-placement program has short-term and long-term effects. A longterm effect on the refugee-receiving municipalities is that they receive new immigrant inhabitants. However, the input of immigrants is mainly short-term because they have a propensity to move away from these municipalities. It is a pity for these municipalities because they then lose this potential human capital to other regions. This can also be seen in Vuolijoki. There the number of immigrants is high compared to the total population, but the municipality's net out-migration is also very high. It can be said that this is a kind of transit area for immigrants.

The migration behavior of immigrants in country-internal migration corresponds to the main flow of migration in Finland, i.e. out-migration from the north to the south. Migration propensity is higher among immigrants compared to Finnish citizens: $7.6 \%$ of immigrants have moved during 2001 in country-internal migration and the corresponding rate for Finnish citizens was $5.4 \%$. This difference is explained partly by the young age structure of immigrants. In general, the migration propensity declines with the life cycle. The percentage of those who are of working age (15-64 years old) is $75 \%$ for immigrants and only $67 \%$ for the population as a whole.

\section{Regional labor market status of immigrants}

The following is an analysis of the changes in the labor market status of immigrants after settling in the country. The material for the gross-stream analysis consists of data analyzed according to the education and occupation of the immigrant population in the primary field of activity in the nine local labor-market area case studies. The gross-stream data serves to show the mobility between different labor-market status groups from 1996 to 1997. Hence, it is possible to determine what has occurred in the labor market by the end of 1997 to an immigrant who was unemployed in 1996; whether she/he has been employed following the migration, if she/he is still unemployed or perhaps outside the labor force.

The target group in the study is the working-age immigrant population (16-74-yearolds) in the nine local labor-market areas in 1996-97. The year they immigrated was 1996. Three groups of labor markets differing in size were chosen for the study: Helsinki, Tampere and Turku representing the major cities, the regional centers represented by Oulu, Jyväskylä and Rovaniemi, and the smaller centers by Rauma, Kajaani and Lohja (Figure 5). According to the statistics for employment in 1996, a local labor-market area consists of a central municipality and its surrounding municipali- 
ties from which at least $10 \%$ of the employed commute to the central municipality. The regional division dates from 1 January, 1999.

Figure 5. The nine Finnish local labor-market areas included in the study, in 1996.

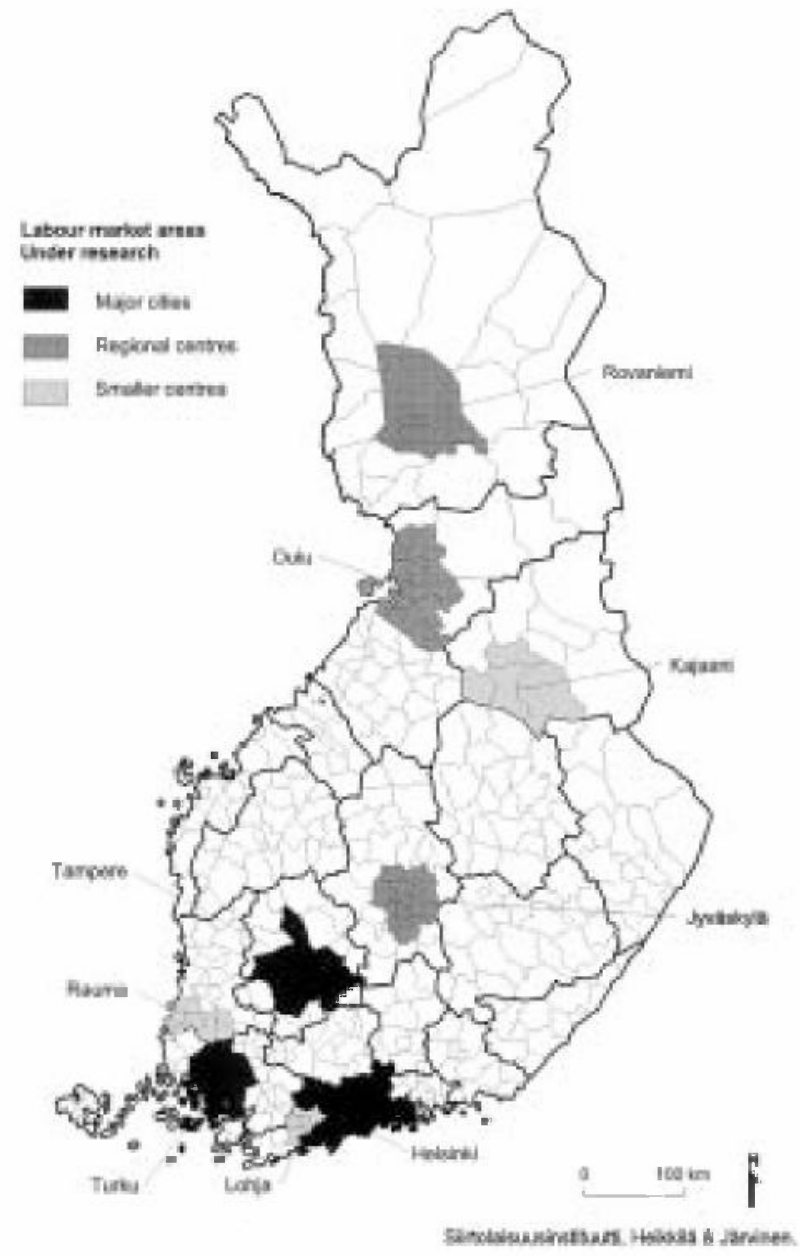

Two-thirds of the immigrants who are of working age have settled in the Helsinki local labor-market area (Table 3). Turku and Tampere have nearly the same number of immigrants; in general, the larger the center, the more immigrants there are. One-third of the persons who immigrated to Finland in 1996 had been recruited by the end of 1997, whereas one-fifth are still unemployed. There are significant differences between the local labor-market areas. The unemployment rate is highest in Jyväskylä where over $30 \%$ of the immigrants are unemployed. There is a higher percentage of students in Turku than in the other areas. A relatively large amount of other groups (housewives, conscripts, pensioners etc.), which are not included in the labor force, are relatively most highly represented in Rauma but are greatest in number in Helsinki (1,300 persons). 
Table 3. Immigrants aged 16-74 years in 1996 and their position in the Finnish labor markets in 1997 (\%) (Data: Statistics Finland).

\begin{tabular}{lccccc}
\hline $\begin{array}{c}\text { Labor-market } \\
\text { area }\end{array}$ & $\begin{array}{c}\text { Number of } \\
\text { immigrants } \\
\mathbf{1 9 9 6}\end{array}$ & $\begin{array}{c}\text { Employed } \\
\mathbf{1 9 9 7}\end{array}$ & $\begin{array}{c}\text { Unemployed } \\
\mathbf{1 9 9 7}\end{array}$ & $\begin{array}{c}\text { Students } \\
\mathbf{1 9 9 7}\end{array}$ & $\begin{array}{c}\text { Others outside } \\
\text { labor force 1997 }\end{array}$ \\
\hline Helsinki & 4,052 & 37.0 & 20.3 & 10.7 & 32.0 \\
Turku & 694 & 25.1 & 15.0 & 29.3 & 30.7 \\
Tampere & 605 & 32.1 & 24.3 & 16.9 & 26.7 \\
Jyväskylä & 251 & 22.7 & 30.7 & 13.9 & 32.7 \\
Oulu & 269 & 34.9 & 17.5 & 16.0 & 31.6 \\
Rovaniemi & 87 & 29.9 & 24.1 & 18.4 & 27.6 \\
Rauma & 49 & 26.5 & 22.5 & 10.2 & 40.8 \\
Lohja & 62 & 29.0 & 19.4 & 24.2 & 27.4 \\
Kajaani & 31 & 25.8 & 25.8 & 12.9 & 35.5 \\
Total & 6,102 & 34.2 & 20.5 & 14.0 & 31.3 \\
\hline
\end{tabular}

The unemployment rate of immigrants was three times higher than the rate of the total population in 1994 (Figure 6). Unemployment has decreased in both groups after the economic recession at the end of the $1990 \mathrm{~s}$. The relative difference between the groups in 2001, however, was still three times that of the total population (immigrant unemployment was $31.5 \%$, and that of the total population $9 \%$ ). There is a large difference in the degree of unemployment between different ethnic groups. For example, the unemployment rate for Iraqi immigrants was $74 \%$ while only $9 \%$ of the French immigrants were unemployed in the year 2000 . According to Jaakkola (2000a) a dual system has developed in the recruitment of immigrants. The immigrants who have succeeded in finding work in Finland are usually college-educated Westerners, while those who have not succeeded usually come from third-world countries, possess little education and working experience.

Figure 6 . The unemployment rates for immigrants and the total population between 1994-2001 in Finland (Source: Monitori 2002), \%.

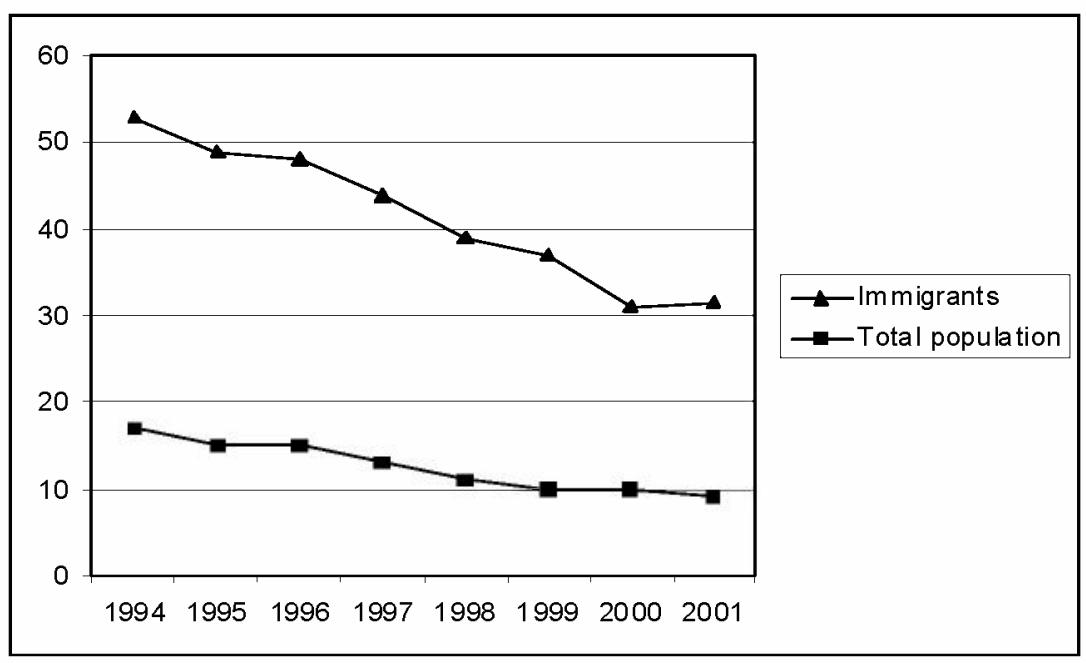


When looking at the total population of Finland, it has been noted that migration has increased the likelihood of getting a job for unemployed people compared to unemployed people who stayed where they were. When the proportion of locals and nonlocals is examined according to having found a new job and by level of education, a general feature that can be seen is that the higher the educational profile of a job position, the more often it is possible for a person coming from outside the local labor-market area to be chosen to fill it (Heikkilä and Korhonen 2002).

Sixty-six percent of the highly educated immigrants chose to settle in the Helsinki area in 1996. The total figure rises to $90 \%$ when including the Turku and Tampere areas. In comparison, most immigrants who possess at least an upper-level higher education have moved to Jyväskylä. Immigrants who possess a basic education or whose level of education is unknown have settled mostly in the labor market areas of Rauma, Lohja, and Kajaani (Table 4).

Table 4. Educational level of immigrants in the nine local labor-market areas in Finland in 1996, \%.

\begin{tabular}{lcccccc}
\hline & $\begin{array}{c}\text { Basic } \\
\text { education } \\
\text { or } \\
\text { education } \\
\text { unknown }\end{array}$ & $\begin{array}{c}\text { Lower } \\
\text { inter- } \\
\text { mediate } \\
\text { level }\end{array}$ & $\begin{array}{c}\text { Upper } \\
\text { inter- } \\
\text { mediate } \\
\text { level }\end{array}$ & $\begin{array}{c}\text { Lower- } \\
\text { level } \\
\text { higher } \\
\text { education }\end{array}$ & $\begin{array}{c}\text { Upper- } \\
\text { level } \\
\text { higher } \\
\text { education }\end{array}$ & Total \\
\hline Helsinki & 57.6 & 7.3 & 17.7 & 8.6 & 8.8 & 100.0 \\
Turku & 57.9 & 9.5 & 14.3 & 8.6 & 9.7 & 100.0 \\
Tampere & 59.2 & 10.9 & 14.7 & 5.6 & 9.6 & 100.0 \\
Jyväskylä & 51.0 & 10.7 & 18.3 & 9.6 & 10.4 & 100.0 \\
Oulu & 58.7 & 11.1 & 14.9 & 8.2 & 7.1 & 100.0 \\
Rovaniemi & 67.8 & 12.6 & 10.4 & 4.6 & 4.6 & 100.0 \\
Rauma & 73.5 & 4.1 & 12.2 & 4.1 & 6.1 & 100.0 \\
Lohja & 77.4 & 4.8 & 11.3 & 1.6 & 4.9 & 100.0 \\
Kajaani & 74.2 & 9.7 & 6.4 & 6.5 & 3.2 & 100.0 \\
\hline
\end{tabular}

When examining the labor-market status of immigrants who came to Finland in 1996 according to their level of education in 1997, one can see that the areas of Helsinki and Oulu have been most successful in employing educated immigrants (Table 5 on next page). Seventy percent of the immigrants in these areas who possess at least a Master's degree or higher have been employed, while only $42 \%$ in the Jyväskylä area have found work. A notable amount of immigrants in Turku who possess a lower intermediate level of education are outside the labor force. Although they already have a degree, most of them are students. Half of the immigrants who possess a lowerlevel higher education have continued their studies in the fields of technology and natural science. The number of immigrants who possess an upper-level higher education is divided evenly between the different fields of science. 
Table 5. The labor-market status of immigrants counted by their level of education one year after immigration to Finland in the nine local labor-market areas in 1997, \%.

\begin{tabular}{|c|c|c|c|c|c|c|c|c|c|}
\hline & Helsinki & Turku & Tampere & $\begin{array}{c}\text { Jyväs- } \\
\text { kylä }\end{array}$ & Oulu & $\begin{array}{l}\text { Rova- } \\
\text { niemi }\end{array}$ & Rauma & Lohja & Kajaani \\
\hline \multicolumn{10}{|c|}{ Basic education or education unknown } \\
\hline Employed & 27.7 & 19.4 & 26.8 & 13.3 & 20.3 & 23.7 & 22.2 & 29.2 & 26.1 \\
\hline Unemployed & 18.6 & 13.9 & 21.2 & 25.8 & 17.7 & 25.4 & 22.2 & 20.8 & 21.7 \\
\hline Student & 10.1 & 24.6 & 16.2 & 14.1 & 20.3 & 15.2 & 11.1 & 27.1 & 13.0 \\
\hline $\begin{array}{l}\text { Other outside } \\
\text { labor force } \\
\text { Lower interm }\end{array}$ & $\begin{array}{c}43.6 \\
\text { liate level }\end{array}$ & 42.1 & 35.8 & 46.8 & 41.7 & 35.7 & 44.5 & 22.9 & 39.2 \\
\hline Employed & 40.0 & 21.2 & 31.8 & 14.8 & 53.3 & 45.4 & 50.0 & 33.3 & 66.7 \\
\hline Unemployed & 27.5 & 24.2 & 39.4 & 40.7 & 26.7 & 36.4 & 0.0 & 33.3 & 33.3 \\
\hline Student & 10.5 & 37.9 & 24.2 & 25.9 & 6.7 & 0.0 & 0.0 & 0.0 & 0.0 \\
\hline $\begin{array}{l}\text { Other outside } \\
\text { labor force } \\
\text { Upper interm }\end{array}$ & $\begin{array}{c}22.0 \\
\text { liate level }\end{array}$ & 16.7 & 4.6 & 18.6 & 13.3 & 18.2 & 50.0 & 33.4 & 0.0 \\
\hline Employed & 42.7 & 27.3 & 29.2 & 32.6 & 55.0 & 44.4 & 16.7 & 28.6 & 0.0 \\
\hline Unemployed & 23.8 & 14.1 & 33.7 & 37.0 & 12.5 & 0.0 & 50.0 & 0.0 & 50.0 \\
\hline Student & 17.0 & 43.4 & 18.0 & 10.9 & 17.5 & 55.5 & 16.7 & 28.6 & 0.0 \\
\hline $\begin{array}{l}\text { Other outside } \\
\text { labor force } \\
\text { Lower-level h }\end{array}$ & $\begin{array}{c}16.5 \\
\text { her educat }\end{array}$ & 15.2 & 19.1 & 19.5 & 15.0 & 0.1 & 16.6 & 42.8 & 50.0 \\
\hline Employed & 52.6 & 33.3 & 41.2 & 41.7 & 50.0 & 25.0 & 0.0 & 100.0 & 0.0 \\
\hline Unemployed & 24.8 & 16.7 & 17.6 & 33.3 & 18.2 & 25.0 & 0.0 & 0.0 & 0.0 \\
\hline Student & 8.6 & 33.3 & 20.6 & 4.2 & 0.0 & 25.0 & 0.0 & 0.0 & 50.0 \\
\hline $\begin{array}{l}\text { Other outside } \\
\text { labor force } \\
\text { Upper-level h }\end{array}$ & her educat & 16.7 & 20.6 & 20.8 & 31.8 & 25.0 & 100.0 & 0.0 & 50.0 \\
\hline Employed & 69.0 & 52.2 & 63.8 & 42.3 & 68.4 & 50.0 & 100.0 & 0.0 & 0.0 \\
\hline Unemployed & 13.5 & 12.0 & 15.5 & 30.8 & 10.5 & 25.0 & 0.0 & 33.3 & 100.0 \\
\hline Student & 3.7 & 23.9 & 8.6 & 15.4 & 10.5 & 25.0 & 0.0 & 0.0 & 0.0 \\
\hline $\begin{array}{l}\text { Other outside } \\
\text { labor force }\end{array}$ & 13.8 & 11.9 & 12.1 & 11.5 & 10.6 & 0.0 & 0.0 & 66.7 & 0.0 \\
\hline
\end{tabular}

Attention should be drawn to the relatively large amount of unemployed immigrants in all of the labor-market areas examined who have a lower intermediate level of education. Their portion is as high as $40 \%$ in the Jyväskylä and Tampere areas. Unemployment is relatively high in many smaller labor-market areas, but the number of immigrants in those areas is also small.

One-third of the unemployed immigrants had found work in the Oulu area one year after immigration in 1997, while only $3 \%$ had found work in Rovaniemi, northern Finland's other center. Correspondingly, Helsinki, Turku, Lohja and Kajaani have employed one-fifth of the unemployed immigrants who have moved to the areas. Oulu has, in comparison, employed most immigrants in industry, business services and the health-care field. Helsinki has employed the largest number of unemployed immigrants. The most important fields of employment have been business services, health care, wholesale businesses, and the hotel and restaurant fields. 
The availability of educated labor is a very important factor for Finland and its regional development. From the regional development point of view, the way in which regions attract human capital and maintain their own human capital is significant. The position of the immigrants on the Finnish labor market is examined with emphasis on the highly educated, employed, 25-34-year-olds in the Helsinki area (Figure 7). This figure shows that in 1996 there were 153 employed immigrants with a higher education in the Helsinki labor-market area, and of these 144 persons were still employed in 1997. Four persons faced unemployment and five had dropped outside the labor force. For 1997 there are 57 new employed immigrants who in 1996 were unemployed (28), students (11) and others outside the labor force (18). The time scale of 1996-97 represents the boom period in the Finnish economy.

Figure 7. Highly-educated immigrants 25-34 years of age in 1996 and their position in the Helsinki labor-market area in 1997 (Data: Statistics Finland).

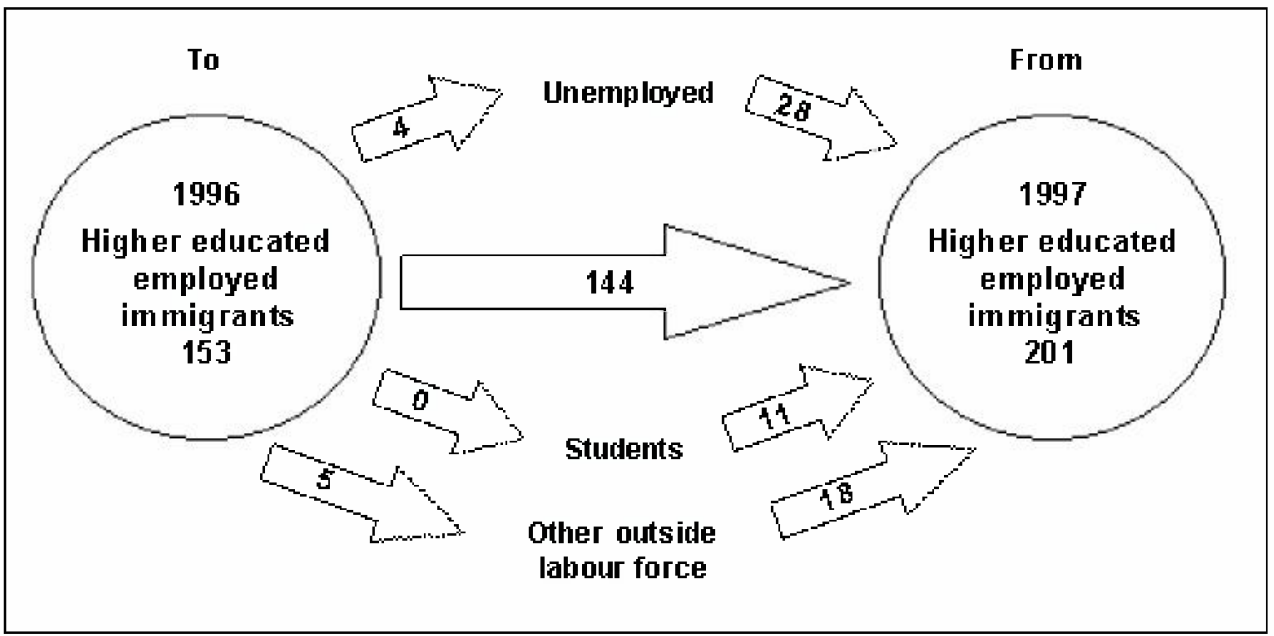

The highly educated play an active role on the labor market in Helsinki labor-market area. Only a few graduates have failed to find work during their stay in Finland. Most of the 25- to 34-year-old graduates are employed in industry, especially in the production of electrical and optical instruments, financing, wholesale trade and agencies, public health and social services and public administration. Men are typically employed in industry, financing, wholesale trade and agencies and women in public health and social services, public administration, wholesale trade and agencies and financing (Heikkilä and Jaakkola 2000). 


\section{Discussion}

Country-internal migration flows among immigrants in Finland has been directed towards southern Finland and especially the growth areas. Their main destination of migration, in this sense, does not differ from that of the native population. Urbanization continues in Finland as the population moves into larger cities. Also, the immigrant population may be concentrated in certain areas within a city as is the case in the eastern suburbs of Turku. For example, $16.8 \%$ of the population in Lauste comprises immigrants and the corresponding proportion for Varissuo is $14.4 \%$. The percentage of immigrants of the total population in the eastern Turku area is $8 \%$ and for all of Turku the figure is 3.6\%. (Turun kaupunki 2002; Kokko 2002; Statistics Finland 2000).

Housing availability is one of the driving forces affecting the regional distribution of immigrants in certain areas within cities because renting is the main form of housing for immigrants. At the end of $1997,64 \%$ of the immigrants rented apartments. Five percent lived in apartments supplied by their employer (see Forsander 2002, 114). This presents a challenge for city planning and for broader city policies.

Differences in country-internal migration motives for the Finns and immigrants are evident. The most significant reasons for the Finns to move from one town/city to another are work, studies, living and changes in family relationships. The four main reasons for immigrants moving to another town/city are wanting to be near friends and family, employment and educational opportunities, wanting to be near people of the same ethnic group, and the need to feel less lonely. Motives concerning living circumstances were not nearly as important to immigrants as they were to the Finns. The basis for migration in search of work or education is different for the Finns and immigrants. Immigrants are more encouraged to move to another town/city although they are not entirely sure what awaits them. They believe that the employment and educational opportunities will be better in the new town/city, especially in growth areas. (Kokko 2002, 85; see Itäpuisto 1999).

One finding of the research is that transit areas of a kind exist for immigrants. This can be seen, for example, in the refugee-receiving municipality of Vuolijoki. The proportion of immigrants of the total population is high there, although the out-migration of immigrants is remarkably strong.

Since 1997, refugees have been placed in municipalities outside the capital area of Helsinki as part of a so-called municipality-placement program. The dispersion of refugees to different areas of the country has been criticized. According to critics, the receiving system cannot offer enough support to the refugees' cultural identity as a result of the dispersion policy (Forsander 2002, 116-117). 
There has been discussion in recent years concerning the availability of the labor force when the baby-boom generation retires. One solution is to allow more immigration. A so-called active immigration policy has prompted discussion especially in eastern Finland because the eastern regions face losses in country-internal migration. This has distorted the structure of the population, especially in the countryside.

The attitudes of the Finns towards immigration have been divided. On the one hand, internationalization, cultural diversity, and immigrants as demographic and economic resources are seen as positive input. On the other hand, some feel that immigrants are a burden; increased immigration brings more people for the Finnish government to support (Pitkänen and Atjonen 2002).

Personal contact with foreigners living in Finland has been connected with positive attitudes towards immigrants. Those who were in contact with foreigners living in Finland had the most positive attitudes toward refugees and foreign jobseekers than those who knew none, or only one or two foreigners. People living in the Helsinki metropolitan area, women, and those who were highly educated possessed the most positive attitudes towards immigrants, and also knew the most foreigners living in Finland (Jaakkola 2000a, 150).

\section{References}

Etnisten suhteiden neuvottelukunta. 1999. Maahanmuutto, pakolaisuus, siirtolaisuus ja etniset vähemmistöt 1990-luvulla. Tutkimukset ja tilastot. Työhallinnon julkaisu 238. Työministeriö.

Forsander, Annika. 2001. Immigrants in the Finnish Labor Market - Is There Ethnic Segmentation? In: Muuttoliikkeet vuosituhannen vaihtuessa -halutaanko niitä ohjata? Munttoliikesymposium 2000 Turku 22.-24.11., edited by Elli Heikkilä, pp. 250-266. Siirtolaisuusinstituutti, Siirtolaisuustutkimuksia A 24.

Forsander, Annika. 2002. Luottamuksen ehdot. Maahanmuuttajat 1990-luvun suomalaisilla työmarkkinoilla. [ Conditions of trust. Immigrants in the Finnish labor market of the 1990s.] Väestöntutkimuslaitoksen julkaisusarja D 39/2002. Helsinki: Väestöntutkimuslaitos, Väestöliitto.

Heikkilä, Elli. 1999. Siirtolaisuusinstituutin tutkimuspoliittinen ohjelma vuosille 2000-2004. Moniste. Siirtolaisuusinstituutti. Turku.

Heikkilä, Elli and Sirpa Korhonen. 2002. The performance of the Finnish labor markets in the 1990s. Institute of Migration, Web Reports 1. Available from: http://www.utu.fi/erill/instmigr/art/Heikkila-Korhonen.pdf

Heikkilä, Elli and Selene Peltonen. 2002. Immigrants and integration in Finland. Survey: About the situation of Immigrants and Refugees in Six Baltic Sea States. Developed within the framework of the European Community Action, SOCRATES. Available from: http: Ilwww.baltic-migration.com 
Heikkilä, Elli and Timo Jaakkola. 2000. The economic status of immigrants in the Finnish labor market. In: NGP Yearbook 2000, edited by Jani Vuolteenaho and Topi Äikäs, pp. 5975. Nordia Geographical Publications 29:2.

Itäpuisto, Timo. 1999. Kotipesänä Pohjanmaa. Etelä-Pohjanmaan muuttajat ja kotiseudulla pysyneet. Siirtolaisuusinstituutin Pohjanmaan aluekeskuksen tutkimuksia 2.

Jaakkola, Magdalena. 2000a. Finnish Attitudes towards Immigrants in 1987-1999. Yearbook of Population Research in Finland, 36, pp. 129-161. The Population Research Institute, The Family Federation of Finland.

Jaakkola, Timo. 2000b. Maahanmuuttajat ja etniset vähemmistöt työhönotossa ja työelämäs$s \ddot{a}$. Työministeriö, Työpoliittinen tutkimus 218.

Kokko, Karoliina. 2002. Maahanmuuttajien Suomen sisäinen muuttoliike. Tapaustutkimuksena Turku. Turun yliopisto, maantieteen laitos, pro gradu-työ. Available from: http: \www.utu.fi/erill/instmigr/art/kokko.pdf

Monitori. 2002. Monitori 2/2002. Maahanmuuttoasioiden ammattilehti. Tilastoliite. Työministeriö.

Pehkonen, Aini. 2002. Maalle muuttajat.[Mobility to the rural areas]. Presentation at Muuttoliikkeen ja etnisyystutkimuksen (MEV) -seminar 6.6.2002 in Institute of Migration, Turku.

Pitkänen, Pirkko and Päivi Atjonen. 2002. Kohti aktiivista maahanmuuttopolitiikkaa. Kulttuurinen monimuotoisuus Itä-Suomen yrityselämässä. Joensuu: Joensuun yliopisto.

Statistics Finland 2000. Aliens and international migration 1999. Population 2000: 10. Helsinki: Statistics Finland.

Statistics Finland. 2002. Foreigners and international migration. Population 2002:8.

Turun kaupunki. 2002. Itä-Turun tavoite 2 -ohjelma. [cited 16 October 2002]. Available from:http://www.turku.fi/urban/taustatiedot.html. 